Informatika i sistemy upravleniya. - 2016. - No. 4(50). - P. 87-93.

Kudinov Yu.I. (kaf-inf@stu.lipetsk.ru), Pashchenko F.F., Kelina A.Yu., Volkova A.A.

Lipetsk state technical university

\title{
THE DECOMPOSITION METHOD SETTINGS OF TS FUZZY PI CONTROLLER
}

Proposed decomposition method, optimization settings by means of MATLAB analytical TagachiSugeno (TS) fuzzy PI controller, ensuring the desired quality of the transient process in the closedloop control system.

Keywords: analytical TS fuzzy PI controller, tuning parameters, optimization, decomposition parameters, MATLAB.

DOI: $10.22250 /$ isu.2016.50.87-93

For citation:

Kudinov Yu.I., Pashchenko F.F., Kelina A.Yu., Volkova A.A. THE DECOMPOSITION METHOD SETTINGS OF TS FUZZY PI CONTROLLER // Informatika i sistemy upravleniya. - 2016. - No. 4(50). - P. 87-93. 